International Journal of Biology, Pharmaey and Allied Sciences (IJBPAS) 'A B Bridge Betusen Caboratory and QRendo'

WwW.ijbpas.com

\title{
GEOGRAPHICAL ANALYSIS OF CROP COMBINATIONAND CROP DIVERSIFICATION IN SANGLI DISTRICT (MAHARASHTRA)
}

\author{
SHINDE DD \\ Assistant Professor, Dept. of Geography, Adarsh College, Vita \\ *Corresponding Author: Dr. Dattatray D. Shinde: E Mail: ddshinde19@gmail.com
}

Received $10^{\text {th }}$ June 2021; Revised $11^{\text {th }}$ July 2021; Accepted 20 ${ }^{\text {th }}$ Aug. 2021; Available online $15^{\text {th }}$ Jan. 2022

https://doi.org/10.31032/IJBPAS/2022/11.1.1006

\begin{abstract}
An idea of the agricultural typology and its income can be derived from crop combinations. Such regions provides areal significance and strength of individual crops, to advocate suitable device for planning improvements in the under developed regions. Beside this, they are helpful in the introduction of innovations in agriculture. Crop combination analysis plays vital role in an investigation of agricultural geographic. Agricultural development is depends on crop diversification pattern. The study of crop diversification pattern is important for agricultural planning. The main objective of the present research paper is to find out and analyze the crop combination and crop diversification regions in Sangli district of Maharashtra State. Ruffiullha's maximum Positive deviation method has used to identify the crop combinations and to find crop diversification region, Jasbir Singh's (1976) method of crop diversification is applied. Cropping pattern of the study region is monoculture and three crop combination.
\end{abstract}

Key words: Cropping pattern, crop combination, crop diversification

\section{INTRODUCTION:}

Agricultural geography is one of the important branches of Geography. Agriculture Geography is the science of agriculturally transformed earth's surface with its entire associated physical, social and economic interrelationship as reflected spatially (Andre, 1981). Region is a basic terminology in geographical science. The most celebrated definition of the concept 'Region' is "an area 
that is different from other areas, according to the specified criteria." For agricultural geographer, agricultural region is core region for his research and investigation as compared to other types of region.

Keeping agricultural regionalization at its core, the study of crop combination becomes significant and its helps in wide and better understanding of agricultural geography. Even for the planning and development of agriculture a systematic study of crop combination has engaged the attention of geographers and agricultural land use planners (Hussain, M. 2002).

Crop diversification means rising of a variety of crops involving intensity of competition amongst field crops for cultivable land. "Keener the competition, higher the magnitude of the crop diversification and lesser the competition the greater will the trend towards specialization of monoculture farming where emphasis is one or two crops" (Singh 1976). The farmers all over the world, especially in the developing country, try to grow several crops in their holding in an agricultural year.

\section{Study area:}

Sangli district is located in southern part of Maharashtra lies between $16^{\circ} 43^{\prime}$ to $17^{\circ} 38^{\prime}$ North latitude and $73^{\circ} 41^{\prime}$ to $75^{\circ} 41^{\prime}$ East longitude. The Sangli district is surrounded by the district of Satara on the north western side. Southern part is bounded by Bijapur and Belgum district of Karnataka state. Ratnagiri and Kolhapur district lies on the west of Sangli district.

Area of Sangli district is 8,572 sq. $\mathrm{km}$. It is divided into ten tehsils. As per census of 2011 , the population of the study region is 28 , 20,575 and density of population is 326 person per sq. $\mathrm{km}$. The climate of Sangli district is mostly dominated by Monsoon. As far as rainfall is considered, Western part of the district receives heavy rainfall than Eastern Part. The drainage pattern is mainly contributed by the rivers like Krishna, Warna, Agrani, Yerala, Nanni and Bor.

\section{Objectives:}

The main objective of present study is to find out and analyze the crop combination and crop diversification in Sangli district.

\section{Data collection and methodology:}

The secondary data is the basis of the present study. The related data is collected from the socio - economic review and statistical abstract of district, district gazetteers, reference books etc. Collected data are processed. Investigation unit is regarded as the tehsil. The percentage of crop covered area is calculated by considering area under each crop and total cropped area.

To find crop combination region in 
Sangli district, following Ruffiullha's theoretical value of each crop is drawn by maximum positive deviation method has been maximum positive deviation.

used. As per this method, the percentage and

$$
\mathrm{d}=\frac{\sum \mathrm{D}_{\mathrm{p}}^{2}-\mathrm{D}_{\mathrm{n}}^{2}}{\mathrm{~N}^{2}}
$$

Where

$\mathrm{d}=$ deviation; $\mathrm{Dp}=$ is the positive

differencefrom the median value of the

theoretical curve value; $\mathrm{Dn}=$ is the negative

difference from the median value of the

theoretical curve value; $\mathrm{N}=$ No. of crops or functions

The crop combination patterns are worked out considering tehsil as a study unit. After the calculation crop combination table 1 is prepared and on the basis of these tables analysis and conclusions are drawn.

To find crop diversification region in of crop diversification is applied. The crops having more than 5\% area are considered for calculation of crop diversification index. Formula of crop diversification index (CDI) is as follows, Whereas, ' $\mathrm{X}$ ' crops are those which individually occupy five or more than five percent of crop to the total harvested area in the tehsil.

\section{Crop Combinations for Year 2019 - 20}

As per Rafiullha's method seven tahsils of Sangli district have monoculture crop combination and remaining three tahsis of the district has three crop combinations.

Sangli district, Jasbir Singh's (1976) method

$$
\text { Crop Diversification Index }=\frac{\text { Percentage of total harvested area under ' } X \text { ' crop }}{\text { Number of ' } X \text { ' crop }}
$$

\begin{tabular}{|c|c|c|c|c|}
\hline $\begin{array}{l}\text { S. } \\
\text { N. }\end{array}$ & Tahsil & $\begin{array}{c}\text { Index Value of Crop } \\
\text { Combination }\end{array}$ & $\begin{array}{c}\text { Crop Combination } \\
\text { Category }\end{array}$ & Crops in Combination \\
\hline 1 & Shirala & 289.00 & One & Rice \\
\hline 2 & Walwa & 81.00 & One & Sugarcane \\
\hline 3 & Palus & 97.95 & Three & Sugarcane + Gram + Soybean \\
\hline 4 & Kadegaon & 196.00 & One & Sugarcane \\
\hline 5 & Khanapur & 256.00 & One & Jowar \\
\hline 6 & Atpadi & 400.00 & One & Jowar \\
\hline 7 & Tasgaon & 86.21 & Three & Jowar + Grapes + Sugarcane \\
\hline 8 & Miraj & 729.00 & One & Jowar \\
\hline 9 & K. Mahankal & 144.00 & One & Jowar \\
\hline $\mathbf{1 0}$ & Jath & 75.24 & Three & Jowar + Bajra + Maize \\
\hline \multicolumn{2}{|c|}{ Total District } & 441.00 & One & Jowar \\
\hline
\end{tabular}

Table 1: Tahsil Wise Crop Combination in Sangli district (2019 - 20) 


\section{Monoculture:}

Monoculture is observed in seven tahsils of Sangli district in $2019-20$.

Rice: Shiralatahsil of the Sangli district has a monoculture crop system. The index value of rice as a monoculture is 289 . In Shiraltahsil, about 32.93 per cent area occupied by rice crop out of the total cropped area of the tahsil. Shiralatahsil have highest rainfall intensity and hot and humid climate which is ideal condition for rice cultivation.

Sugarcane: Sugarcane as a monoculture observed in Walwa and Kadegaontahsils of Sangli district. The index value of sugarcane as a monoculture is 81 in Walwa and 196 in Kadegaontahsil. Out of total cropped area of the tahsil, about 40.75 per cent and 36.22 per cent area covered by sugarcane in Walwa and Kadegaontahsils respectively. These tahsil has well developed fertile soil and well developed irrigation facilities due to the presence of river Krishna and Yerla. Due increasing irrigation facilities, favorable climatic condition, development of high yielding verities of sugarcane, increased input of chemical fertilizers also opening of number of sugar factories the sugarcane has been steadily increased.

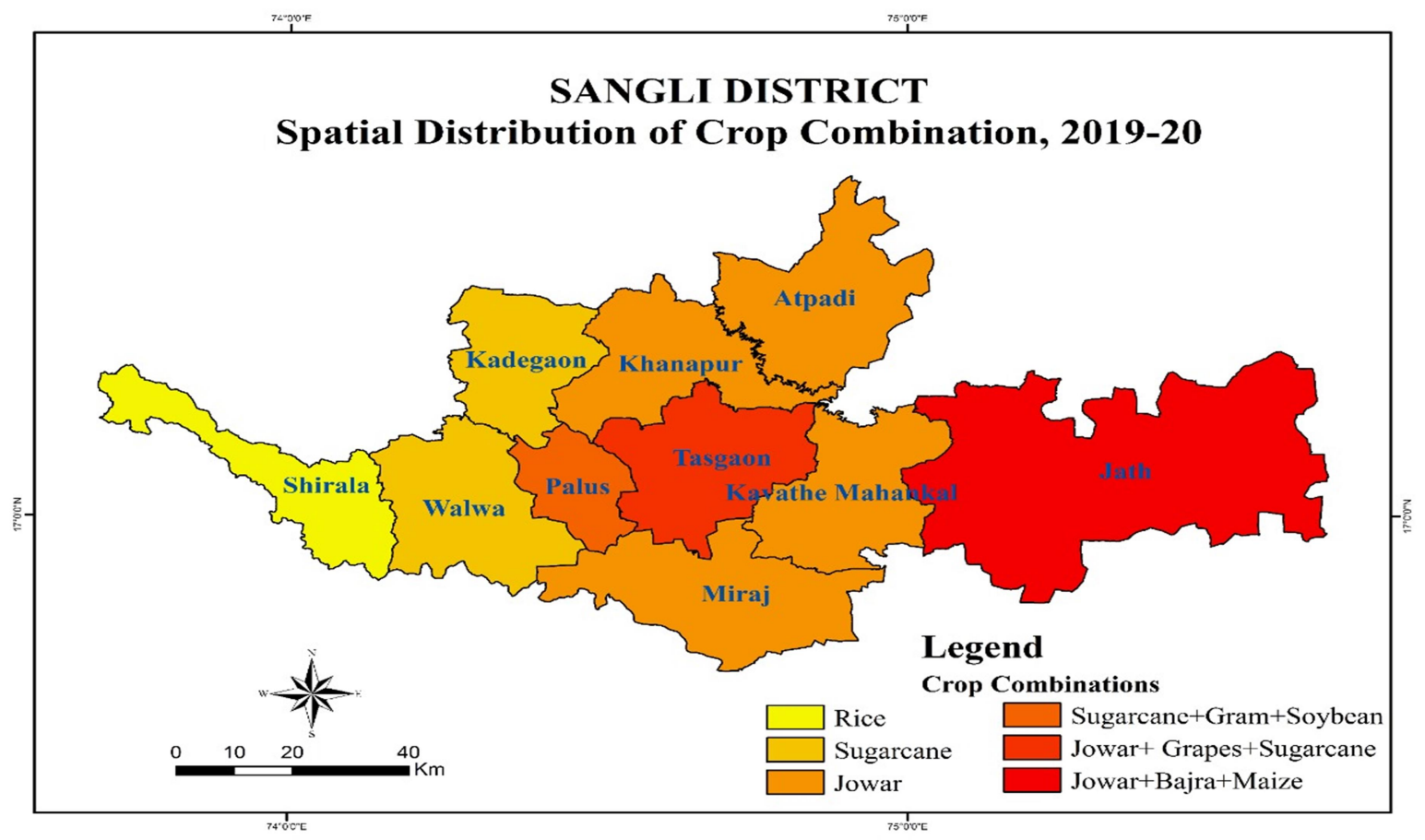

Fig. 2

Jowar: In Khanapur, Atpadi, Miraj and KavatheMahankaltahsilsjowar

monoculture observed due to favorable climatic condition and soil. The index value of 
jowar as a monoculture is 256, 400, 729 and 144 in Khanapur, Atpadi, Miraj and KavatheMahankaltahsils respectively. Jowar is grown in a variety of soils ranging from light sand to heavy clays. Its performance is better in deep and medium black soils. It is raised in kharif and rabi seasons in Khanapur, KavatheMahankal and Mirajtahsils.

\section{Three Crop Combinations:}

Three crop combinations are recorded in Palus, Tasgaon and Jathtahsils of Sangli district in 2019 - 20. However each tehsil have different combination of crops.

\section{Sugarcane - Gram - Soybean:} Sugarcane, gram and soybean crop combination is observed in the Palustahsil of Sangli district. The index value of sugarcanejowar-soybean crop combination is 97.95 . The sugarcane, gram and soybean are the first, second and third ranking crops occupied an area about 47.38, 10.64 and 7.91 per cent respectively out of total cropped area of the Palustahsil. Amount of rainfall, deep black and fertile soil, well developed irrigation facilities are useful for the dominance of sugarcane, gram and soybean in Palustahsil.

Jowar - Grapes -Sugarcane: Jowar, grapes and sugarcane crop combination is recorded in Tasgaontahsil of Sangli district. The index value of these three crop combination is 86.21 . In Tasgaontahsil, jowar is first (44.81 per cent), grapes are second (13.18 per cent) and sugarcane are third (9.91 per cent) ranking crops out of total cropped area of the tahsil. It is mainly raised in the area of jowar, grapes and sugarcane cultivation, availability of suitable climate, well-drained soil, irrigation facility, innovative farmer, skilled labour, proper planning for cultivation practices and development of advanced technology in the central part of the district.

Jowar - Bajra - Maize: In Jathtahsil of Sangli district is observed Jowar, bajra and maize crop combination. The index value of these three crop combination is 75.24 . Jowar is first, bajra is second and maize is third ranking crops out of total cropped area of the Jathtahsil. Drought prone area, scarcity of water supply, well drained also light to shallow poor gray soil are main reasons for jowar, bajra and maize crop combination of the Jathtahsil.

\section{Crop Diversification for Year 2019 - 20}

The crop diversification means growing of multiple crops from the same land. It is observed that various crops are involved in the competition for the diversification. More the number of crops present per tehsil, more crop diversification can be observed in the respective tehsil. 
Table 2: Tahsil Wise Crop Diversification in Sangli district (2019 - 20)

\begin{tabular}{|c|c|c|c|c|c|}
\hline $\begin{array}{l}\text { S. } \\
\text { N. }\end{array}$ & Tahsil & $\begin{array}{c}\text { Index Value of } \\
\text { Crop } \\
\text { Diversification }\end{array}$ & $\begin{array}{c}\text { Crops in Competition for } \\
\text { Diversification }\end{array}$ & $\begin{array}{l}\text { Area in } \\
\text { Hectare }\end{array}$ & $\begin{array}{l}\text { Area in } \\
\text { Per cent }\end{array}$ \\
\hline 1 & Shirala & 14.91 & Ric+Sug+Soy+Gnt+Jor+Maz & 35231 & 89.5 \\
\hline 2 & Walwa & 14.86 & Sug + Soy + Gnt + Jor + Grm + Wht & 78001 & 89.15 \\
\hline 3 & Palus & 15.72 & Sug+Grm+Soy+Gnt+Grp & 22693 & 78.61 \\
\hline 4 & Kadegaon & 16.99 & Sug+Jor+Soy+Gnt+Wht & 43736 & 84.97 \\
\hline 5 & Khanapur & 15.63 & Jor+Maz+Gnt+Sug & 30477 & 62.52 \\
\hline 6 & Atpadi & 16.74 & Jor+Baj+OFr+Lem+Maz & 29621.1 & 83.68 \\
\hline 7 & Tasgaon & 14.27 & Jor+Grp+Sug+Maz+Gnt+Soy & 59944.4 & 85.60 \\
\hline 8 & Miraj & 13.38 & Jor+Sug+Maz+Grp+Soy+Grm & 67135 & 80.29 \\
\hline 9 & K. Mahankal & 16.50 & Jor+Maz+Baj+Sug+Grp & 47243.5 & 82.50 \\
\hline 10 & \begin{tabular}{|c|} 
Jath \\
\end{tabular} & 24.46 & Jor+Baj+Maz & 140992 & 73.39 \\
\hline \multicolumn{2}{|c|}{ Total District } & 13.65 & Jor+Sug+Maz+Baj+Soy & 473781 & 68.23 \\
\hline
\end{tabular}

Source: Computed by researcher based on Socio-Economic Abstract of Sangli District, 2019-20

The table shows the crop

diversification region which have been identified according to range of crop diversification index (CDI).
2. Area of moderate crop diversification (16 to 20$)$

3. Area of low crop diversification (above 20)

1. Area of high crop diversification

(below 16)

Table 3: Crop Diversification Patternin Sangli district (2019 - 20)

\begin{tabular}{|l|c|c|c|}
\hline . N. & Crop Diversification Class & frop Diversification Index Value & Name of the Tehsils \\
\hline $\mathbf{1}$ & High Diversification & Below 16 & $\begin{array}{c}\text { Shirala, Walwa, Palus, } \\
\text { Khanapur,Tasgaon,Miraj }\end{array}$ \\
\hline $\mathbf{2}$ & Moderate Diversification & $\mathbf{1 6 - 2 0}$ & Kadegaon, Atpadi, KavtheMahankal \\
\hline 3 & Low Diversification & Above 20 & Jath \\
\hline
\end{tabular}

Source: Computed by researcher based on Socio-Economic Abstract of Sangli District, 2019-20

High crop diversification region: Area with high diversification is observed insix tehsils viz, Shirala (14.91), Walwa (14.86), Palus (15.72), Khanapur (15.63),Tasgaon (14.27) and Miraj (13.38)tehsils during 2019 - 20 in the study region. The main crops cultivated in these tehsils havejowar, maize, sugarcane, soybean, groundnut, gram, wheat and grapes.
The rice crop is cultivated only in the Shirala tehsil. It is observed that, these tehsils have high degree of diversification due to inputs to irrigation, fertilizers, pesticides, improved seed etc. Due to the extension of irrigation, the farmers of these tehsils have changed their attention from food grains to cash crops such as sugarcane, fruits and oil seeds. 


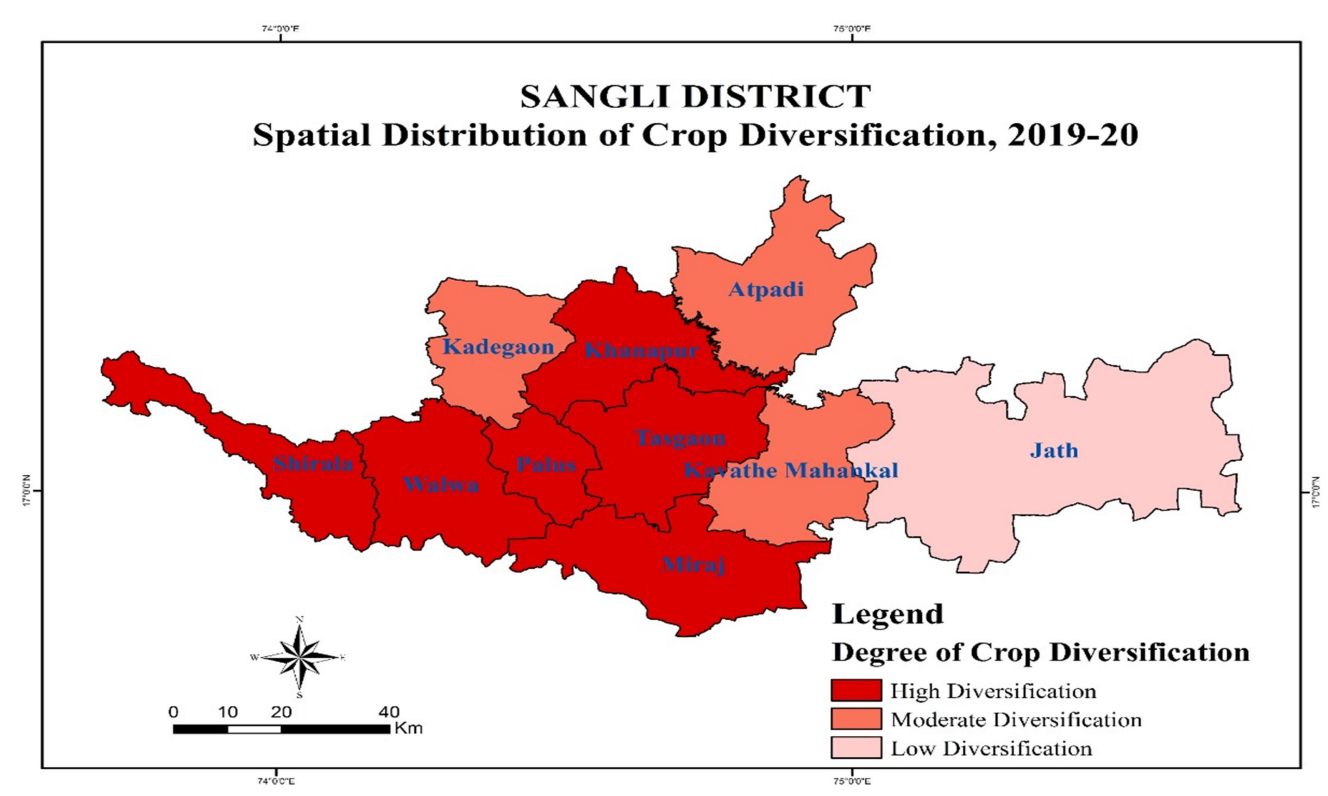

Fig. 3

Moderate crop diversification region: It is observed that three Kadegaon (16.99), Atpadi (16.74) and Kavthe Mahankal (16.50) tehsils have noticed high crop diversification in 2019 - 20 in the study region. The major crops cultivated in these tehsils have sugarcane, jorwar, soybean, groundnut, wheat, bajra etc.

Low crop diversification region: Low crop diversification is found in only Jath (24.46) tahsil during $2019-20$. The main reason behind low crop diversification is the limited irrigation facilities, very scanty rainfall and poor quality of soil. Therefore, mainly food grain crops are grown in this tehsil like jowar, bajra etc.

\section{CONCLUSION:}

The cropping pattern of Sangli district relies on various factors such as nature, socio-economic structure and the technology used for agriculture. Monoculture is observed in Shirala, Walwa, Kadegaon, Khanapur, Atpadi, Miraj, Kavathe Mahankal and three crop combinations are recorded in remaining Palus, Tasgaon and Jath tahsils of Sangli district in 2019 - 20. In Shiralatahsil rice as a monoculture crop is present. This is due to high amount of rainfall, hot and humid climate. The tahsils Walwa and Kadegaon has the sugarcane as a monoculture crop. This is caused due to the presence of fertile soil, well developed irrigation facilities, development of high yielding verities of sugarcane, increased input of chemical fertilizers. In Khanapur, Atpadi, Miraj and Kavathe Mahankal tahsils hasjowar as a monoculture crop due to favorable climatic condition and soil. Sugarcane, gram and soybean crop combination is observed in the Palus tahsil due 
to amount of rainfall, deep black and fertile soil, well developed irrigation facilities. In Tasgaon tahsil, Jowar, grapes and sugarcane crop combination is recorded due to well drained soil, suitable climatic condition and irrigation facility. Eastern rain fed Jathtahsil has Jowar, bajra and maize crop combination.

The result of crop diversification index shows that the most of tehsils have diversification rather than specialization due to development in agricultural technologies. The highest diversification is found in Shirala, Walwa, Palus, Khanapur, Tasgaon and Miraj tehsils whereas lowest diversification is observed in only Jath tehsil in the year 2019 20.

\section{REFRENCES:}

[1] Bhatia S. S. (1965),Pattern of Crop Concentration and Diversification in India, Economic Geography, Vol. 41, No. 1

[2] Gatade D. G. and Pol N. S. (2012), Crop Combination in Sangli District (Maharashtra): A Geographical Analysis, Variorum Multi Disciplinary e - Research Journal, Vol. 03, Issue - I, August 2012

[3] Nanaware A. H., Jadhav S. S. and Jadhav L. G. (2013), A Geographical Analysis of Crop Combination in Marathwada Region, Maharashtra Bhugolshastra Sanshodhan Patrika, ISSN 0971 - 6785, Vol. XXX Issue 1, 2013
[4] Kadam M. D. and Shinde S. D. (2018), Crop Diversification Regions in Sina River Basin: Maharashtra, Maharashtra Bhugolshastra Sanshodhan Patrika, Vol. 35, No. 1, Jan-Jun 2018.

[5] Kuniyal J. C. (1998), Crop Combination Region in District Nainital U.P. Himalaya, The Deccan Geographer, Vol. XXVI, No. 1, p. 271 -281 .

[6] M. Husain (2002), Systamatic Agricultural Geography, Rawat Publication Jaipur

[7] Mulani S. M. (2012), Crop Combination in Solapur District 2011: A Geographical Analysis, Review of Research, Vol. 2, Issue 2, Nov. 2012, pp. $1-4$.

[8] Neerja K., Krishna reddy B. and Ramaniah Y. V. (2004), Crop Regions, Crop Combinations and Crop Diversification in Nellore District, Andhra Pradesh, The Indian Geographical Journal, Volume 79, pp. 45-50.

[9] Socio Economic Review and Statistical Abstract of Sangli District 2020

[10] ShekharAngadi and Raymane A. S. (2018), Crop Combination of Dakshin Kannada District: A Geographical Study, Review of Research, ISSN: 2249 - 894X, Impact Factor: 5.2331 (UIF), Volume. 7, Issue - 4, January 2018. 